\title{
Nationality Diversity in Academia: What is the Problem Represented to be?'
}

\section{Tatiana Maximova-Mentzoni²}

PhD, Senior Researcher, The Work Research Institute, OsloMet - Oslo Metropolitan University, Norway

\section{Cathrine Egeland}

PhD, Research Professor, The Work Research Institute, OsloMet - Oslo Metropolitan University, Norway

\begin{abstract}
This article investigates problem representations of nationality diversity at higher education and research institutions in Nonway and in the other Nordic countries. Nationality diversity refers to different nationalities among academic staff that increases language, value and information diversity in organizations. Employing a 'What's the problem represented to be' approach, we uncover problem representations identified in previous Nordic research on nationality diversity in academia as well as in a recent case study on nationality diversity at Norwegian higher education and research institutions. While the literature review identifies different problem representations, explores their underlying conceptual logics and describes how these problem representations are formed, the Nonwegian case study intends to address problem representations that seem to be left unproblematic both in previous research and organizational practices in Norwegian academia.
\end{abstract}

\section{KEYWORDS}

Diversity management / higher education and research sector / inclusion / internationalization / nationality diversity / Norway

\section{Introduction}

iversity among staff, including nationality diversity ${ }^{1}$, in higher education and research is increasingly being formulated as a political value in Norway and in the other Nordic countries in the same way that gender equality has been for many years (Mählck \& Thaver 2010; Sandell 2014b). Universities and university colleges issue policy documents aimed at promoting and supporting diversity. However, as for gender equality in academia, problematizations underlining the need for nationality diversity policies are implicit and hidden between the lines. This is because nationality diversity, like gender equality, is an abstract category that needs to be understood in different historical and institutional contexts (Bacchi \& Goodwin 2016).

Over the past decades, higher education and research institutions both in the Nordic region and globally have undergone a radical institutional, economic and cultural change from being privileged, self-recruiting and self-regulating organizations, to becoming more international and performance-oriented, challenged by

\footnotetext{
${ }^{1}$ You can find this text and its DOI at https://tidsskrift.dk/njwls/index.

${ }^{2}$ Corresponding author: Tatiana Maximova-Mentzoni. E-mail: tatima@oslomet.no.
} 
growing demands for capitalist market orientation and transnational academic mobility (Gornitzka et al. 2008; Zippel 2017). A number of research reports have examined the composition and characteristics of foreign-born academic staff (Børing \& Gunnes 2012; Gunnes et al. 2017; Olsen 2013; Olsen \& Sarpebakken 2011). However, there is little research to date on how nationality diversity is understood and viewed by foreign-born academic staff and how the organizations in academia have responded to the new reality of increased nationality diversity among personnel. In the context of the Nordic countries, this research is quite recent (Jonasson et al. 2018; Lauring \& Selmer 2013; Mählck 2016; Sandell 2014a), as is the case worldwide.

The fact that 'nationality diversity among academic staff' in the Nordic countries is a relatively new field of research may be explained by the growing proportion of immigrants in society in general and a greater political focus on integration and inclusion, which is also reflected in academia. In recent years, there has also been a greater focus on internationalization, which has led to increasing international academic mobility and the emergence of an international labor market for academics. Many academic institutions have experienced a 'generational shift' and the need to renew senior positions in academia, also by means of international recruitment (Maximova-Mentzoni, Egeland et al. 2016).

With this article, we wish to contribute to the emerging field of research on nationality diversity in academia and the organizational response to the higher number of foreign-born academics. Firstly, we seek to uncover problem representations with regard to nationality diversity at higher education and research institutions identified in previous Nordic research on nationality diversity in academia. Secondly, we further expand the knowledge by including new insights on problem representations from the case study on nationality diversity in Norwegian academia. In this article, we employ the analytical focus of the What's the Problem Represented to be? - approach (WPR) (Bacchi 2018; Bacchi \& Goodwin 2016). We are particularly interested in identifying different problem representations of nationality diversity, exploring the discursive logics that underlie these problem representations and how these problem representations come about, as well as addressing what is left unproblematic. We apply the WPR approach to both the literature review and the case study. Before we proceed with the findings of the problem representations, we provide a brief outline of the WPR approach and study method.

\section{Problematizations of nationality diversity through the prism of the WPR approach}

Our contribution is rooted in the WPR approach (Bacchi 1999, 2018, 2009; Bacchi \& Goodwin 2016) and the concept of 'problem representation' (Bacchi 1999, 2009) that stresses 'implicit representations of what is considered to be the "problem" (Bacchi 2012:20). The key term here is 'representation' rather than 'problem', as the point of departure for the analysis is not identified 'real problems' but existing 'solutions' such as knowledge base, higher education internationalization policies, diversity policies and diversity practices at universities, which often implicitly and sometimes explicitly reveal what seems to be problematic with regard to nationality diversity in academia. As Bacchi and Goodwin (2016: 21) put it: "we start from stated "solutions" to inquire into their implicit problematization(s)'. The existing solutions constitute a governance tool or, we add, a management tool to deal with the 'problem', as what they 
propose to do something about indicates what needs to change and hence what the 'problem' is assumed to be.

According to Osborne (1997: 174), 'policy cannot get to work without first problematizing its territory'. In a similar way, we suggest that the development of specific organizational practices, in this case within management of nationality diversity in academia, also presupposes certain prior problematizations, or, as asserted by Bacchi, representations of problems. Diversity management has recently emerged as a new task in Norwegian and Nordic higher education and research institutions following governmental legislation on anti-discrimination and equality. In organizational literature, diversity management is often referred to as '... the systematic and planned commitment by organizations to recruit, retain, reward, and promote a heterogeneous mix of employees' (Ivancevich \& Gilbert 2000: 75). Internationally, diversity management has become a prominent field of research in management and organization studies, referring empirically to the specific programs, policies and practices that organizations have developed and implemented to manage a diverse workforce effectively and to promote organizational equality (Nkomo \& Hoobler 2014; Prasad \& Mills 1997; Zanoni et al. 2010). Over the past two decades, critical diversity scholars have questioned the implementation of diversity practices without necessarily placing the practices in the organizational or institutional context of the problem they are a solution to (Dennissen et al. 2018; Janssens \& Zanoni 2014; Nkomo \& Hoobler 2014; Prasad \& Mills 1997; Zanoni et al. 2010). Understanding what nationality diversity problem the diversity management practices intend to fix and how these problematizations come about is in line with this critical approach to diversity management.

Problematization is in fact another key term in the WPR approach, which stresses how the 'problems' come about. Within this frame of reference, political and social problems are not fixed or unequivocal, they are questionable. Problems are established through interpretations, negotiations of meaning, and choices that have implications for 'how the phenomena in question are understood and how the objects of governance are constructed in hegemonic discourses, how they are treated and also how they are interpellated to understand themselves and their own situation' (Bacchi 2009:1). Policies, practices and the 'problems' they respond to are not the result of a natural or neutral development, but rather of political discussions and negotiations in shifting historical and social circumstances.

The concept of problem representation has in recent years been developed into a poststructural analytical strategy for critical analysis - WPR approach (What's the Problem Represented to be?) (Bacchi 2018; Bacchi \& Goodwin 2016). It has been applied in studies beyond policy analysis, promising an innovative perspective also in the context of organization studies. In this article, we apply the WPR approach both to the literature review of nationality diversity in Nordic academia and to the case study of nationality diversity in the context of Norwegian higher education and research institutions. The essence of this analytical strategy is that it approaches 'knowledge', such as that produced in research, policy documents and interview transcripts, as 'levers' to open up reflections on forms of governance, to uncover what is hidden in the 'knowledge' and question given forms of proposals. Thus, the purpose of the analysis, in our case of nationality diversity in academia, is to identify the meanings, reconstruct them and interrogate problematizations. One example discussed in detail in this article is subjectification, which is common in policies categorizing people, foreign-born academics in our case, as a particular kind of 'governable subjects'. Subjectification potentially affects 
peoples' lives, as it tends to produce practices to divide majorities and minorities, thus eliminating particular problem representations (Bacchi \& Goodwin 2016).

\section{Overview of the study and data}

In the following, we give a short presentation of the data collection methods, both the literature review and the case study. The data were collected as a part of a unique research project ${ }^{2}$ investigating career paths and obstacles for foreign-born academics in Norway (Authors 2016). The collected data have been analyzed applying the WPR approach as discussed above.

\section{Literature review}

The search strategy for the literature review aimed to collect existing research addressing 'nationality diversity among employees in academia' in the Nordic countries. The search was broadly defined in order to identify existing research in various areas, such as recruiting nationality diversity to academia; employment conditions for staff with an immigrant background in academia; career barriers related to ethnicity; the working environment at universities and university colleges that are multicultural workplaces; as well as nationality diversity policy, and management in academia.

The population was defined as 'persons with an immigrant background who apply for jobs or are employed in teaching and research positions at universities or university colleges'. Thus, words such as 'ethnicity', 'diversity', 'immigrant' and 'foreign' were relevant search terms. The search was limited to one geographic area - the Nordic region, and the latest publication year, 2015. To hone our focus, we excluded (1) studies that examine types of diversity other than nationality diversity, and without any correlation to the ethnicity of employees; (2) studies on ethnic diversity among students in the higher education sector; and (3) studies on ethnic diversity in other parts of the education system. Otherwise, the search was fairly open in relation to the inclusion criteria. The search was conducted in Norwegian, Swedish, Danish and English. Therefore, the search did not include literature in Finnish or Icelandic, and contributions on the topic of nationality diversity in academia in these languages were not included in this study.

The search was conducted in the relevant Nordic and international databases such as Oria, LIBRIS.se, DFF (forskningsdatabasen.dk), Kora.dk, Nordart, Arbline, Sciencedirect, Escohost, Scopus, Social Sciences Citation Index and EPIC. The librarian at NIFU assisted with part of the literature search. Example of a search combination:

(higher education OR academia OR research) AND (staff OR faculty) AND (diversity OR migrant OR ethnic OR colour) AND (nordic OR scandinavian OR norway OR sweden OR denmark OR iceland OR finland OR norwegian OR swedish OR finnish OR danish OR icelandic).

In the databases where it was technically possible to search titles and abstracts, we refined the searches accordingly. In other databases, such as ORIA, we searched the full text. In addition to the search library catalogues, we used some alternative methods, 
such as a review of the bibliographies of identified relevant literature as well as tips from experts in the field.

The search identified 20 academic papers ${ }^{3}$ that fulfilled the inclusion criteria. The academic contributions reviewed in this study have rather different focuses. The literature review therefore gives a broad indication of what nationality diversity problems are represented to be in research in the Nordic region. It is important to note that several articles included in the review are small-scale empirical studies. Some publications base their argument purely on a literature review and a document analysis, while others base their reasoning on a few interviews with foreign-born academic staff. This reflects the exploratory nature of current research in this field. This may be a result of inadequate funding for this field of research that would enable more complex studies.

\section{The case study in Norway}

The case study in Norway was conducted at three institutions. These were a traditional university, a university college and an independent research institute. The organizations thus differed considerably in terms of financial model, size, organizational structure and disciplinary/professional profile. The selected case institutions ensured that the data collected had a geographic, institutional/sectoral (both the higher education and research sectors) and academic/discipline-based distribution. Our intention was not to compare these cases, but rather to identify common trends relating to nationality diversity.

Our decision to use a case study approach was based on the explorative nature of the research project. This design is particularly well suited for research questions starting with how and why, and when the focus of the research is a contemporary phenomenon (Yin 2004). Our ambition was not to obtain representative data, but rather to gain insight into aspects of increasing nationality diversity in academia and the challenges this raises in academic organizations.

The case study method included a document analysis of two diversity or equality plans in two different organizations, as well as individual semi-structured interviews with foreign-born academic staff and representatives of the academic administration, and one group interview with foreign-born academic staff. A total of 26 people were interviewed, of whom nine were administration representatives and 17 were foreignborn academic staff. The academic administration interviewees held different positions: one HR director, one institute director, two heads of studies, three research institute managers and two diversity and equality advisors. The foreign-born academic staff interviewees had been in Norway for between 2 and 30 years and most of them had a $\mathrm{PhD}$ and a permanent academic position. The majority came from a European country outside the Nordic countries and had come to Norway at an early age and had subsequently obtained a Norwegian degree, often both a master's degree and a PhD. A minority of the interviewees had been internationally recruited. The majority furthermore had backgrounds in hard sciences such as technology, medicine, IT and natural sciences, while only three interviewees had backgrounds in soft sciences, such as psychology, linguistics and special pedagogics. This reflects the current distribution of foreign-born academic staff among disciplinary fields and subjects in the Norwegian higher education and research sector in general (Gunnes et al. 2017). 
Most interviews were conducted in Norwegian. A few interviews with newly arrived foreign-born academic staff were conducted in English. Thematically, the interviews with the foreign-born academic staff centered around the interviewees' own career paths, experiences of mobility, recruitment, diversity and discrimination in their own institutions, formal and informal selection processes, as well as academic and workplace cultures. Interviews with representatives of the academic management and administration focused on organizational awareness of nationality diversity, recruitment processes, diversity or equality strategies, and nationality diversity management practices. The purpose of these interviews was to learn if and how the institutions work specifically and strategically to promote diversity among employees in academic positions, and if the practices and strategies in this area are in accordance with or, on the contrary, compete with other practices at, and the goals and strategies of the institutions.

With regard to the WPR analysis, the scope and character of the identified problem representations may be limited due to the representations of the informants who agreed to participate in the study and their dominant experiences and opinions.

\section{Problem representations of nationality diversity in academia in previous research}

Our first research aim is to uncover problem representations as identified in previous Nordic research on nationality diversity in academia. In the following, we explore this research question using the literature review data and the WPR analysis as described earlier. Our analysis depicts problem representations related to subjectification of nationality diversity, access to academia, workplace inclusion and those described in the policy discourses.

\section{Problem representations through subjectification}

Categories are important in policy-making, as they identify a target group for policies and further organizational practices. Several Nordic studies, in one way or another, problematize subjectification (ref. Bacchi \& Goodwin 2016) of nationality diversity in academia (Hoffman 2007; Sandell 2014a) through the complexity of the category 'nationality diversity' and the effects of different nationality diversity groups on organizations differ.

One problem representation is the complexity of the category 'nationality diversity' and the lack of group nuances in policy and organizational practice, which leaves some groups potentially neglected, lacking support or recognition. With regard to ethnic diversity among academic staff in Finland, Hoffman (2007) argues that 'local' and 'international employees' are clear-cut categories. Other groups of foreign-born academics, such as those who migrated for reasons other than internationalization, seem to be neglected both in terms of support and knowledge about particular inclusion challenges:

If you're ethnically Finnish or 'international' on campus, there are clear opportunities and infrastructure. If you are something other than those two things [...] you are in an interesting situation in which very little knowledge exists and even less professional capacity (Hoffman 2007: 129). 
The invisibility of some groups of foreign-born academics is also problematized in several Swedish studies (e.g., Andersson 2014; Mählck 2012, 2013; Mählck \& Fellesson 2014; Mählck \& Thaver 2010) with particular emphasis on the issue of 'race' among academic staff. The problem representation of nationality diversity in these studies concerns color-blindness in academia promoting an image of 'racialized' or 'non-white' academic staff as outsiders or 'visitors'. Despite their senior positions in higher education and research, these 'representatives of diversity' feel that they constantly have to prove their competence and academic credibility in order to gain recognition for their work in academic circles. Both Mählck (2013) and Andersson (2014) highlight the importance of addressing visible diversity in order to understand how inequalities in higher education and research institutions are created and maintained.

Another problem representation with regard to subjectification of nationality diversity in academia concerns the different effects different types of nationality diversity have on higher education and research institutions. The problem represented to be is that different types of diversity impact differently on group processes with regard to solving tasks, group dynamics and group productivity. This makes establishing and managing heterogeneous groups to 'create task-relevant compositions of staff diversity' challenging for university management. Lauring and Selmer (2013) encountered this problem representation when they examined how different types of diversity impact on openness among faculty staff in reference to various types of differences - differences in language (linguistic diversity), values (value diversity), appearance (visible diversity) and information (informational diversity). In higher education and research institutions in Denmark, Lauring and Selmer (2013) found that the diversity characteristics of academic staff that stem from internationalization - in this study, cultural and linguistic diversity - have a positive correlation to openness to diversity, while diversity characteristics stemming from demographic indicators such as gender and age have a negative correlation or no correlation to openness to diversity. This finding represents a potential challenge for university administrators in managing multicultural groups and securing inclusive workspaces.

\section{More challenging access to academia for foreign-born academic staff}

One of the most evident problem representations concerning nationality diversity in academia revealed in current research is more challenging access to academia for foreign-born academic staff. The assumptions underpinning this problem representation vary somewhat, but together demonstrate the exclusion mechanisms identified through skewness in disciplinary affiliation, prerequisites for successful academic careers typical for foreign-born academics as well as institutional discrimination, which we elaborate further here.

Several Nordic studies discuss the problem of skewness in disciplinary affiliation of foreign-born academics. Research shows that in Norway, the majority of foreignborn academic staff work within the subject areas of mathematics, natural sciences and technology. The lowest proportion of foreign-born academic staff appears to be in the social sciences (Børing \& Gunnes 2012; Gunnes et al. 2017; Maximova-Mentzoni et al. 2016). Hoffman (2007) observes the same in the Finnish higher education and research sectors, concluding that it is easier to find foreign-born academics in 'hard-applied' 
disciplinary fields such as clinical medicine, engineering, IT, biotechnology, etc, as well as 'soft-applied' disciplinary fields such as business, language, art, etc. In the 'pure' disciplines, such as physics, mathematics and anthropology, the prevalence of foreign-born academic staff is very low. Any foreign-born academic staff working within these disciplines are the exception rather than the rule. Some Swedish studies (e.g., Göransson \& Lidegran 2005; Saxonberg \& Sawer 2006) confirm a similar pattern in the disciplinary profile of foreign-born academic staff in Sweden. Foreign-born academics have a greater chance of a successful academic career in medicine, technology and natural sciences, and lowest chance in the social sciences and humanities.

More challenging access to academia for foreign-born academic staff is also related to particular individual characteristics of foreign-born academics and their success in establishing themselves in their field. According to Göransson and Lidegran (2005), there are several aspects that can determine whether a foreign-born academic will have a successful career path. These are social background, gender, current family situation, disciplinary field and topic, how much 'teaching capital' they have, the status of their native country in Sweden and which life phase they were in when they immigrated. For example, the study shows that the prerequisites for success are better for those from a North American or Nordic country. Academics who immigrated at a young age and have completed their compulsory education, upper secondary education and higher education in Sweden are more likely to compete on an equal footing with Swedes due to proficiency in the local language, established networks and knowledge of the rules (Göransson \& Lidegran 2005).

Some studies examined the problem of more challenging access to academia for foreign-born academics by addressing exclusion mechanisms at the system level. Saxonberg and Sawer (2006), focusing on recruitment to academic positions within the social science disciplines of economic history, psychology, sociology and political science in Sweden, conclude that it is not discrimination, but rather the existence of exclusionary institutional mechanisms that has a negative impact on this group, and which thus constitutes the problem. This may be explained by the tendency to recruit internally, the importance of belonging to the 'right' network, knowledge of unwritten rules in certain universities and university colleges, knowledge of the mechanisms for academic career development in Sweden, belonging to particular theoretical traditions and recruitment procedures that are easy to manipulate. Saxonberg and Sawer (2006) explain the problem representation by pointing to 'cultural cloning' - a process in which a university replicates itself by employing recognizable candidates.

\section{More challenging workplace inclusion}

Another problem representation of nationality diversity in academia addressed in several studies concerns more challenging workplace inclusion for foreign-born academic staff. This problem representation highlights the issues of local language mastery, the invisibility of foreign-born academic staff as well as extra emotional work for representatives of nationality diversity.

One of the key challenges to workplace inclusion discussed in previous studies is insufficient mastery of local language or language diversity as such when a foreign-born employee masters the local language, but when this is still insufficient to fit in. Mählck 
and Thaver (2010) equate proficiency in Swedish with the possibility for foreign-born academics to be included in 'the inner power circles' in the faculties. In her study of foreign-born academic staff in Sweden, Andersson (2014) concludes that even when foreign-born academics master Swedish, they still cite the language issue as a factor that creates extra challenges in their work. These challenges appear in the interaction with students who may have a stigmatizing attitude toward a foreign-born lecturer by questioning his/her disciplinary competence based on accent or mastery of the Swedish language. Other challenges appear in connection with written text correction, which takes longer for non-native speakers of Swedish, as well as in unfavorable work situations with management and colleagues. Andersson (2014) concludes that foreign-born academics who do not use their own native language in work situations where the majority use their native language have to use extra energy to prove their competence and intellectual capacity, and to fight their corner in challenging situations.

De los Reyes (2010) discusses another aspect that challenges the workplace inclusion of foreign-born academic staff: silence surrounding invisibility. Her study shows that foreign-born academic staff in Sweden experienced everyday discrimination in that they felt invisible and ignored. This is particularly evident in connection with the recognition of their academic competence, which they felt was often perceived by others as less valuable in an academic sense than that of their Swedish colleagues. De los Reyes (2010) believes that both silence and invisibility are used to maintain and legitimize boundaries between belonging and exclusion, and between the norm and deviations that are constructed through the minority dimension of ethnicity. These day-to-day experiences of feeling invisible may impact health, as self-image is challenged and extra emotional strength is required to fit in. Andersson (2014) discusses the problem of more challenging work inclusion by accentuating additional emotional work for foreign-born employees. Foreign-born academics often have to deal with feelings of being treated differently in their everyday work - in addition to their normal work duties. This is reflected in the employee having to work harder than their colleagues by constantly having to prove their competence and intellectuality, by being exposed to other people's 'suspicions', and by having to deal with 'extreme feelings of uncertainty' and insecurity in their encounters with colleagues and students (Andersson 2014).

\section{Problem representations based on analysis of policy discourse}

The final part of the analysis on the previous research looked into research that had explicitly analyzed policy documents. We concentrated on these as government-level policy documents represent solutions to nationality diversity problems in academia, and therefore are source of problem representations. Some Nordic scholars have examined policy documents and highlighted such problem representations of nationality diversity as (1) inadequate equality and diversity legislation that supports the invisibility of foreign-born academics and workplace inclusion challenges; (2) an implicit 'us-them' difference promoted through universities' positive image of internationalization; and (3) the lack of an intersectional perspective in the policy documents, which ignores the triple disadvantage foreign-born 'non-white' female academic staff experience.

Schömer (2014) and Espersson (2014) problematize the prevailing focus on eliminating discrimination in equality and diversity efforts in higher education and research 
institutions. Schömer (2014) considers this to be a passive approach based on antidiscrimination legislation overseeing institutional discrimination challenges. Schömer (2014) believes it is not possible to change the current exclusive structures within the existing legal framework, precisely because the legislation is based on the principle of equal treatment. This principle does not take into account the different structures in which people live and work, giving more privileges to already privileged groups. Espersson (2014) supports this conclusion by making a link between equality efforts and meritocracy, ideals where gender and ethnicity should not play any role in recruitment and career development in higher education and research institutions, as everyone should be treated equally regardless of their background and appearance. Meanwhile, research shows that there are real differences in career opportunities between women and men and between foreign-born and local academics (Espersson 2014). This problem representation seems to support the need for subjectification of nationality diversity and the challenges experienced by foreign-born academic staff in order to develop policy solutions and promote organizational practices that, to a greater extent, create more inclusive academic workplaces.

Another problem representation scholars highlight based on analyses of policy documents refers to internationalization promoting an 'us-them difference'. Andersson (2014) and Andersson (2010) point out that internationalization and diversity are frequently and unquestionably introduced as positive characteristics of universities and research institutes where representatives of diversity are counted and referred to as the results of internationalization efforts. This promotes a focus on a university's image rather than fair treatment of nationality diversity and inclusion. This is because the presence of 'representatives of diversity' as employees in academia is linked to background rather than competence, as if foreign-born academic staff are recruited because of their minority background rather than their qualifications and academic merits. Analyses of policy documents on diversity at Lund University led Schmidt (2014) to reach a similar conclusion.

Mählck and Thaver (2010) raise another problem representation based on policy document analysis: a lack of intersectional perspectives in the policy documents.

They argue that the debates on gender and ethnicity among academic staff seem to counteract each other, with the discourse on ethnicity tending to replace the discourse on gender. Researchers believe that these discourses should instead be viewed in conjunction with each other. In her studies on the recruitment of academic staff in Sweden, Mählck (2012, 2015) observes that nonwhite women who immigrated from non-Western countries will be more exposed to discrimination than white Western women, pointing to the triple disadvantage foreign-born 'non-white' female academic staff experience. Schmitt (2014) and Schömer (2014) support the argument criticising universities' diversity documents for primarily focusing on various minority categories without an intersectional perspective.

The WPR analysis of the literature review data has identified problem representations in regard to subjectification of nationality diversity, access to academia, workplace inclusion, equality and diversity legislation, the lack of an intersectional perspective in the policy documents as well as universities' representation of internationalization. In what follows, we will present findings from the Norwegian case study in order to explore the discursive logics that underlie these problem representations and how these problem representations come about, as well as addressing what is left unproblematic.

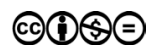




\section{Problem representations of nationality diversity in the case of Norwegian academia}

The second research aim of this study is to further expand the knowledge on nationality diversity in academia by broadening the scope of problem representations emerging from the literature review by including findings from the Norwegian case study.

In Norway, the state has invested in developing competitive academic environments with the ambition of attracting talented researchers and students from all over the world (Ministry of Education and Research 2018). From 2007 to 2014, the percentage of foreign-born academic personnel in the Norwegian higher education and research sectors increased from $17 \%$ to $25 \%$ (Gunnes et al. 2017). This increase has been especially pronounced in temporary academic positions such as postdoctoral and research project positions, where the percentage of foreign-born personnel in 2014 was 49\% (Gunnes et al. 2017). The concept of diversity has moved up the political agenda in Norway and has to some extent influenced institutional and organizational practices, also in the higher education and research sector. Established in 2004, the Norwegian Committee for Gender Balance and Diversity in Research expanded its mandate in 2014 to also include a focus on nationality and ethnic diversity. Several recent white papers and public documents accentuate the need for and importance of ensuring diversity and equal treatment in public workplaces. As part of this development, diversity management has emerged as a new task in Norwegian higher education and research institutions.

Broadening the scope of problem representations emerging from the literature review data by including data from the case study, we have identified and formulated additional problem representations of nationality diversity, which we discuss further below.

\section{Challenging subjectification of nationality diversity in organizational practice}

The WPR analysis of the literature review data revealed the need to unpack 'nationality diversity' in policy and organizational practice in order to adjust management efforts. An important discourse on diversity in academia, also addressed by Andersson (2014), concerns the construction of 'diversity representatives'. When is what relevant in terms of diversity in academia? And for who?

The analysis of the documents and interviews in the case study identified a common recruitment practice in Norwegian academia that can be formulated almost as a slogan: 'Everyone is welcome regardless of their background'. However, once the recruitment process was completed, the administration in all the case institutions approached the foreign-born staff as 'international', 'immigrants', 'non-Norwegian', or in any case, not belonging to the majority. This categorization was considered correct in terms of HR as the administration in order to implement good HR work in relation to the minority groups in the academic staff and prevent discrimination caused by ignorance of the challenges relating to their minority and immigrant status. However, these categorizations and identity markers ignored foreign-born academics' need to belong and to be approached based on their academic merits, rather than their immigrant background. 
Most of the interviewees among the academic staff had experienced being approached in a different way than employees with a majority background, that is, 'the Norwegians', which was the term consistently used by the informants. They felt that they were treated like outsiders or 'guests'. What the interviewees among the academic staff found particularly problematic was that their Norwegian colleagues often spoke of how lucky the interviewees were to have obtained an academic position at a Norwegian higher education or research institution. 'You're so lucky!' was in some cases followed by negative remarks about the country that the interviewee had left. What was never communicated, according to the interviewees was: 'We're so lucky to have you here'. Instead of being recognized for their academic merits and expertise, they felt that they were treated like representatives of some cultural or ethnic particularity, as 'guests' who could potentially turn out to be a burden.

The interviewees emphasized that their academic achievements and experience, not their nationality, should be the focus of attention and grounds for inclusion in academia. In addition, some interviewees highlighted positive aspects of being 'representatives' of diversity, in terms of experience of different academic cultural frames of reference.

The analysis of the case study data identified a new problem representation: how can diversity in academia best be facilitated without focusing on the specific 'representatives of diversity' and 'their' interests and needs as 'different' at the expense of a focus on individual competencies, academic merits and organizational structures? Hoffman (2007) believes that with the changing demographic context in Finland - which also applies to the rest of the Nordic countries - the conceptual understanding of foreigners among academic staff needs to be expanded. How 'foreign' are foreigners among academic staff when some of them obtain local citizenship or a permanent residence permit? In order to understand the mechanisms behind academic mobility, recruitment and retention of foreign-born academic staff in the Nordic countries, we need to understand the different nuances the term 'nationality diversity' brings to academia.

\section{Need to extend organizational practices from recruitment to inclusion}

As pointed out in the literature review, foreign-born academic staff experience more challenging workplace inclusion (Andersson 2014; De los Reyes 2010; Mählck \& Thaver 2010; Saxonberg \& Sawer 2006) due to local language mastery, invisibility as well as extra emotional work for representatives of nationality diversity. Our study contributes a new problem representation: organizational practices for nationality diversity neglect the need for stronger organizational emphasis on inclusion of nationality diversity.

Our case study shows that both HR and the academic administration at the various case institutions worked in a purposeful and careful manner to ensure recruitment of sought-after competence, regardless of background, as well as transparency in the recruitment processes. However, the challenges foreign-born academic staff experienced fitting in at a workplace were neglected and regarded as unproblematic. The interviewees explained that while the foreign-born academics perceived the recruitment phase as well-functioning, they did not feel included in the institutions because of their foreign background.

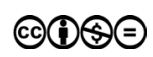


A number of our informants described situations where they felt ignored, overlooked or even excluded. They spoke of phrases or expressions that were used to put people in their place - a kind of show of power to demonstrate who was 'boss' of the department. For instance: 'You're "stusselig” [eng.: pitiful], but you probably don't understand what that means.' Or: 'You don't know so much, you have to understand ... there's something you need to learn here'. Utterances like these can be perceived as disparaging, and define the recipient of the message as someone who is not included, an outsider.

The interviewees among foreign-born academic staff also explained exclusionary internal communication and group dynamics at the institutions. Some interviewees had experienced being ignored or not being listened to at collegial meetings, with the majority paying no attention to their opinions or suggestions. Some had experienced repeatedly being told that it would be wiser to 'shut up' than to try to contribute in plenary sessions. In such situations, interviewees felt that their contributions and initiatives were worthless because they were foreigners and thus outsiders.

Moreover, some had experienced stagnation in their professional development during their employment in the Norwegian higher education and research sector. They experienced obstacles that prevented them from launching and realizing their ideas concerning, for instance, the development of new courses or study programs, or teaching subjects in which they excelled. They experienced what they perceived to be considerable opposition to innovative thinking from both colleagues and the institution's academic administration.

Other informants did not describe their workplace as an explicitly exclusionary environment, but rather as less inclusive than desired. Several informants pointed out that it is more challenging to have successful social relations with Norwegian colleagues. One academic administration informant who also had a migrant background explained it as follows:

There's a kind of culture crash when you come to Scandinavia, it takes longer to get to know people, to become friends and to start talking. [...] I have good Norwegian friends, but I know that it takes longer than it does other places in Europe.

Some academic administration representatives, mostly at institution or group level, seemed to recognize the problem of challenging workplace inclusion for foreign-born academic staff. However, they found it a challenging problem to address due to other obligations and the lack of resources as exemplified in the following quote from an administration representative:

I have a very busy working day, so it's difficult to prioritize [diversity work]. Unfortunately, there's not much time for it during an ordinary day. The [case institution] must make an effort in so many other areas before prioritizing such wide-ranging initiatives. First, we have to deal with everyday problems: overworked staff, no premises available, and people working from eight in the morning until eight at night. [...] It's a kind of Maslow's hierarchy of needs. [...] it's too early to talk about the top of the pyramid if the foundation isn't in place

To summarize, the problem representation discussed here concerns the dominant focus on recruitment of diversity in organizational practices and overseeing the need to 
strengthen organizational efforts on inclusion. As discussed previously, recruitment is an important focus area given that foreign-born academic staff experience challenges in making a career in academia. However, we add that focusing on recruitment alone is not enough to retain good foreign-born academics. Nor is it enough to develop and benefit from the potential and resources that foreign-born academics often represent. Our study identifies a need for more comprehensive efforts on workplace inclusion in the higher education sector, as this aspect of diversity management is not currently accentuated or widespread.

\section{Organizational diversity policies overseeing challenges in gaining equal opportunities}

Another problem representation of nationality diversity emerges in what seems to be an insufficient focus in organizational diversity policy documents overseeing challenges foreign-born academics face in gaining equal opportunities. In line with problematization raised by Schömer (2014) and Espersson (2014), we wish to nuance the problem representation by addressing it in the context of organizational practice.

In our case institutions, a great deal of emphasis has been put on efforts to develop organizational diversity or equality plans that cover, inter alia, nationality diversity. The diversity/equality plans were considered to be evidence of the institutions' willingness and ability to follow government guidelines, promote equality and prevent discrimination. These plans were developed based on the government anti-discrimination law, which does not take invisible exclusion mechanisms and institutional discrimination in academia into account.

Those informants who were foreign-born academic staff had not experienced explicit discrimination based on skin color, religion or cultural background. What they instead draw attention to in their narratives is the gap between the Norwegian selfunderstanding of being a society dominated by ideals of equality, openness and participation, and what they experienced as the existence of powerful (but not spoken about) networks and nepotism in Norwegian academia. The informants reacted to the relationship between the ideal and reality. One foreign-born academic staff informant explained it in the following:

I've experienced that the situation and the conditions are different for Norwegians. [The management] makes an extra effort to create a position, adapt things for them, but they don't make the same effort for a foreigner with a similar degree. [...] Norwegians talk an awful lot about [the crisis in] Southern Europe - you know 'That kind of thing [corruption] happens in Greece and Italy and Turkey' - but it's happening in Norway as well! Things like this, they do actually happen here. It's just a bit more ... disguised ... polished and well presented.

Equality and diversity are highlighted as core values at the case institutions and are anchored in top management. Whether the diversity work is equally well anchored at lower management levels is, on the other hand, an open question. The need to introduce a culture of inclusion was broached in several interviews. Both representatives of foreign-born academic staff and academic administration argued for the establishment

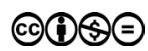


of an organizational culture that fosters respect for individuals and differences. This was regarded as a more proactive and ambitious approach to promoting and securing equality than the anti-discrimination legislation. A representative of the academic administration explained:

It's part of the culture and culture building. Respect not only for diversity, but for the person. We all have different levels of culture and understanding. So there must be some scheme in [case institution] that encourages communication, openness, respect for all employees, and respect for a different kind of life. But I don't know if this is possible, [...] it's difficult to change it, and it's not considered an important issue.

Continuing the line of argument in the works of Schömer (2014) and Espersson (2014), we add that organizational diversity policies, as well as governmental legislation and national diversity policies, oversee challenges foreign-born academics face in gaining equal opportunities. This might be explained by the previous focus on anti-discrimination, which is not the same as access to equal opportunities. Our informants problematized challenging access to equal opportunities in academia through their experiences of internal recruitment, institutional discrimination, cultural barriers and insufficient workplace inclusion. This indicates that national and organizational diversity policies may require an additional element: they also need to emphasize challenging access to equal opportunities and promote measures to strengthen it.

\section{Need for organizational change to allow excellence through internationalization}

The literature review addressed the issue of internationalization and diversity being frequently, but without a discussion highlighted as positive characteristics of universities and research institutes (Andersson 2010,2014). This is also the case in Norway where academic institutions' ambitions for achieving excellence via internationalization do not problematize what this means in terms of organizational redesign, thus ensuring that internationalization efforts actually lead to excellence. Interviews gave further insight into this topic.

Several interviewees, both among the academic staff and academic administration, stated that their institution was poorly equipped for internationalization, despite having ambitions in this area. Most vacancies were still only advertised in Norwegian. The culture of communicating in English was inadequate, which was perceived as the main challenge for advancing excellence through foreign-born academic employees. One interviewee said that a foreign colleague had to resign after a short time because he did not feel included, he 'felt left out at meetings'. In addition, not mastering the local language, which is evident for most of the internationally recruited academics during their first years in Norway, prevents foreign-born academic staff from understanding both the formal and the informal rules of the game in connection with positions, promotion, rules concerning temporary and permanent employment, etc.

Previous Nordic research underlines that language in higher education and research institutions serves to create inclusion and exclusion cultures in faculties (Mählck \& Thaver 2010; Saxonberg \& Sawer 2006). At the same time, scholars question whether using 
English as a shared language is the solution to the inclusion problem. In their quantitative study at universities in Denmark, Selmer et al. (2013) demonstrate that the use of a shared language, despite improving communication, did not have a direct effect on work processes since the differences between employees were deeply rooted in terms of value and informational diversity. Whether introducing English as the language of communication is a negative or a positive development for the academic workplace is not in itself a topic in this problem representation. However, the discussion on working languages is important in connection with nationality diversity in academia because it highlights challenges that are not easily solved. This not only concerns whether universities stop using local languages in favor of English or whether and how foreign-born academic staff can learn Norwegian to enable them to integrate as quickly as possible; if anything, but it also relates more to exploring and clarifying the institutions' different and possibly incompatible ambitions.

On the one hand, all three of the case institutions included in this project expressed ambitions to make their academic mark internationally. This also applies to most other institutions in higher education and research in Norway. International publishing, development and exchange of academic resources in the form of increasing academic mobility for both students and employees, and investment in international research projects, are all helping to make English an increasingly prominent working language in Norwegian academia. This may explain why the informants at the case institutions raised the need to establish English as the working language. They found that English was only used as a working language to a limited extent at their institutions, and interpreted this as a sign that the institution's level of ambition in terms of research and internationalization was moderate or low.

At the same time, we found that the informants were well aware of higher education and research institutions in Norway not existing separately from the rest of society. They educate future generations of workers and aim to provide education and research of relevance to Norwegian society. Speaking Norwegian in academia can be viewed as supporting the notion that employees in academia have the opportunity to provide education and research in response to societal challenges.

Balancing ambitions for excellence, diversity, participation and integration, or making a clear distinction between the different ambitions, may be a future challenge for academia. Discussions on working language and diversity are thus not solely related to communication, but are also related to the higher education and research institutions' ambitions, goals and social mission.

\section{Conclusion}

This article contributes to knowledge about what nationality diversity problems are represented to be at higher education and research institutions. By exploring the issue of problem representations in nationality diversity in academia, we draw attention to the complexity of research, policy and practice with regard to nationality diversity in academia.

One of the most highlighted problem representations of nationality diversity is that access to academia is more challenging for foreign-born academic staff. This problem representation is identified in previous Nordic studies through skewness in disciplinary affiliation, prerequisites for successful academic careers typical for foreign-born 
academics as well as institutional discrimination. Our case study provides empirical evidence in support of this problem representation.

Furthermore, our review reveals that careful subjectification of nationality diversity is an increasingly important means of addressing the challenges experienced by different groups of foreign-born academics. The subjectification also seems to be an important means of gaining understanding about what different types of diversity can bring to the table in terms of inclusive workplaces and cooperative knowledge production. The case study develops this problem representation further. We highlight the organizational challenge of facilitating nationality diversity and eliminating the existing exclusion mechanisms without accentuating the 'we-them' difference.

Another nationality diversity problem representation addressed in previous research refers to workplace inclusion being more challenging for foreign-born academic staff. This problem representation is demonstrated via exclusion mechanisms associated with local language mastery, the invisibility of foreign-born academic staff competencies as well as extra emotional work for representatives of nationality diversity that may have negative consequences at the individual level, such as lowered well-being. Our case study acknowledges this problem representation and points to another relevant problem representation, namely the lack of focus on inclusion in management and organizational practices in academia, which has increasingly become multicultural.

Finally, the review of previous research highlights other problem representations that seem important, but that are not currently problematized in policy documents: inadequate equality and diversity policies that do not have a workplace inclusion focus; implicit 'us-them' differences promoted through universities' positive image of internationalization; the lack of intersectional perspectives in policy documents ignoring the triple disadvantage foreign-born 'non-white' female academic staff experience. The Norwegian case study illustrates how anti-discrimination legislation, when practised alone, prevents proactive organizational practices from securing more equal opportunities for foreign-born academics. Moreover, we elaborate on the unproblematized issue of internationalization accentuating the need for organizational change in higher education and research institutions to advance excellence through internationalization.

The applied WPR approach in the analysis, though it enables us to grasp the implicit statements of diverse problem representations, is concerned with reflexivity during the analysis meaning subjectification of own representations of the problem (Bacchi \& Goodwin 2016). Our ambition was not to concentrate on a single theme, favor or prioritize any particular problem representations. We wished to show the multiciplity of problem representations and their different and sometimes conflicting origins as well as to draw attention to the silence surrounding important problematizations in current policy and organizational practice at higher education and research institutions in the Nordic countries.

Nationality diversity in academia is a complex issue. This is not just because comparing the situation and experiences of, for example, a male, German professor with the situation and experiences of a female, Iranian post doc is problematic. It is also complex because diversity, like gender equality, is historically not a 'core value' or an integral part of academia's 'contract' with the rest of society. Problem representations of nationality diversity discussed in this study highlight group differences, inequalities and exclusion. Drawing attention to particular problem representations and their consequences in the design of diversity policies, diversity measures and daily diversity management is crucial if we are to understand and embrace the potential of nationality diversity 
in academia. This can be turned into a positive challenge calling for innovative management approaches to enhance workplace inclusion in order to promote innovation and excellence in academic organizations. Our study indicates that nationality diversity, rather than calling for diversity management, calls for inventive approaches to workplace inclusion to enhance innovation and excellence. We thus agree with Ferdmann (2014) that organizations have to develop practices of inclusion, which provide both a sense of belonging and a sense of uniqueness for all employees (Shore et al. 2011). This is an approach that does not imply that the 'others' should be included in 'our' organization. Rather, it suggests that working toward an inclusive academic organization would benefit everyone, not just 'the others'.

\section{References included in the literature review}

Andersson, M. (2014). Närvaro som märks. Rasifiering och tillhörighetsarbete i den svenska akademin [Discernible presence. Racialization and efforts at belonging in Swedish academia] I: Sandel, K. (ed), Att bryta innanförskapet: Kritiska perspektiv på jämställdhet och mangfald $i$ akademin [Breaking the Insider Cirkle: Critical Perspectives on Equality and Diversity in Academia], Göteborg: Makadam förlag.

de los Reyes, P. (2010). En ojämlik jämställdhet? Intersektionella perspektiv på jämställdhet inom universitetsvärlden [An unequal equality? Intersectional perspectives in the world of universities] I de los Reyes, P. (ed) Vad händer med jämställdheten? Nedslag i jämställdhetens synfält [What happens to equality? Traces in the sight of equality], Uppsala Universitet. Available at: http://jamda.ub.gu.se/handle/1/613.

Espersson, M. (2014). Isärkoppling som strategi. Om spänningen mellan meritokrati och likabehandlingsarbete vid ett svenskt lärosäte [Connecting as strategy. On the tension between meritocracy and equality work in a Swedish higher education institution] I: Sandel, K. (ed), Att bryta innanförskapet: Kritiska perspektiv på jämställdhet och mångfald $i$ akademin [Breaking the insider cirkle: Critical perspectives on equality and diversity in academia], Göteborg: Makadam förlag.

Göransson, A. \& Lidegran, I. (2005). En gränslös akademi? Vägar till den akademiska toppen med utländsk bakgrund i bagaget [A limitless academia? Roads to the academic top equipped with foreign background] In: Makten och maingfalden. Eliter och etnicitet $i$ Sverige. Rapport frä Integrationspolitiska maktutredningens forskningsprogram [Power and diversity. Elites and ethnicity in Sweden. Report from the integration political investigation on power' research program] 2005:012: Available at: http://www.regeringen.se/ rattsdokument/departementsserien-och-promemorior/2005/04/ds-200512/.

Hoffman, D. (2007). The career potential of migrant scholars in Finnish higher education: Emerging perspectives and dynamics. Doctoral Dissertation. Jyväskylä Studies in Education, Psychology and Social Research. No. 318, Jyväskylä University Press.

Lauring, J. \& Selmer, J. (2013). Does staff diversity imply openness to diversity? International Journal of Educational Management 27(6): 631-646. doi: https://doi.org/10.1108/IJEM11-2012-0127.

Mählck, P. (2012). Differentiering och excellens i det nya forskningslandskapet: Om kön, tystnad och performativa vithetshandlingar [Differentiation and excellence in the new landscape of research: On gender, silence and performative actions of whiteness], Tidskrift för Genusvetenskap (1-2): 25-48.

Mählck, P. (2013). Academic women with migrant background in the global knowledge economy: bodies, hierarchies and resistance, Women's Studies International Forum 36: 65-74. doi: https://doi.org/10.1016/j.wsif.2012.09.007. 
Mählck, P. (2015). The racial grammar of Swedish higher education and research policy: the limits and conditions of researching race in a colour-blind context. I: Andreassen, R. \& Vitus, K. (eds), Affectivity and Race Formations. A Nordic Case Study, Farnham: Ashgate.

Mählck, P. (2016). Academics on the move? Gender, race and place in transnational academic mobility, Nordic Journal of Studies in Educational Policy (2-3): 29784. doi: https://doi. org/10.3402/nstep.v2.29784.

Mählck, P. \& Fellesson, M. (2014). Kunskapspolitikens blinda fläck - rasifieringens grammatik $\mathrm{i}$ akademin [The blind spot of the knowledge politics - the grammar of racialization in academia] I: Sandell, K. (ed), Att bryta innanförskapet: kritiska perspektiv på jämställdhet och maingfald $i$ akademin [Breaking the insider cirkle: Critical perspectives on equality and diversity in academia], Göteborg: Makadam förlag.

Mählck, P. \& Thaver, B. (2010). Dialogue on gender and race equality: conversations between Sweden and South Africa, Equality, Diversity and Inclusion: An International Journal 29(1): 23-37. doi: https://doi.org/10.1108/02610151011019192.

Olsen, T. B. (2013). Utlendinger med norsk doktorgrad - hvor blir de av? En undersøkelse basert på registerdata [Foreigners with Norwegian doctoral degree - where are they? A study based on register data] NIFU-report 17-2013: Available at: https://brage.bibsys.no/ xmlui/handle/11250/280423.

Olsen, T. B. \& Sarpebakken, B. (2011). Utlendinger i norsk forskning: En undersøkelse basert på registerdata [Foreigners in Norwegian research: a study base don register data] NIFU-rapport 30-2011. Available at: https://brage.bibsys.no/xmlui/handle/11250/282015.

Sandel, K. (2014a). Att bryta innanförskapet: Kritiska perspektiv på jämställdhet och mångfald $i$ akademin [Breaking the insider cirkle: Critical perspectives on equality and diversity in academia], Göteborg: Makadam förlag.

Sandel, K. (2014b). Minoritiserade grupper mellan policy och villkorad närvaro [Minoritized groups between policy and conditioned presence] I: Sandel, K. (ed), Att bryta innanförskapet: Kritiska perspektiv på jämställdhet och mångfald $i$ akademin [Breaking the insider cirkle: Critical perspectives on equality and diversity in academia], Göteborg: Makadam förlag.

Saxonberg, S. \& Sawer, L. (2006). Uteslutningsmekanismer och etnisk reproduktion inom Akademin [Mechanisms of exclusion and ethnic reproduction in academia] I: Sawyer, L. \& Kamali, M. [ed], Utbildningens dilemma: Demokratiska ideal och andrafierande praxis [The dilemmas of education: democratic ideals and othering practices], Stockholm: Fritze: Available at: http://www.regeringen.se/contentassets/38b1c68cac07410db29c65910627d9e6/utbildningens-dilemma---demokratiska-ideal-och-andrafierande-praxis-sou-200640.

Schmitt, I. (2014). Om begreppens klibbighet och problem: en intersektionell analys av jämställdhets-, likabehandlings- och mångfaldspolicy på Lunds universitet [On the stickyness and problems of concepts: an intersectional analysis of the equality-, equal treatmentand diversity policies at the Lund University] I: Sandel, K. (ed), Att bryta innanförskapet: Kritiska perspektiv på jämställdhet och mångfald $i$ akademin [Breaking the insider cirkle: Critical perspectives on equality and diversity in academia], Göteborg: Makadam förlag.

Schömer, E. (2014). Rättsliga aspekter på möten mellan jämlikhet, jämställdhet och mångfald [Juridical aspects pertaining to the intersection of eqality and diversity] I: Sandel, K. (ed), Att bryta innanförskapet: Kritiska perspektiv på jämställdhet och mångfald $i$ akademin [Breaking the insider cirkle: Critical perspectives on equality and diversity in academia], Göteborg: Makadam förlag.

Selmer, J., Lauring, J. \& Jonasson, C. (2013). Academic staff involvement and openness to diversity in international educational organisations: is there a moderating effect of shared language? Higher Education Quarterly 67(2): 135-156. doi: https://doi.org/10.1111/ hequ. 12008 . 


\section{Other references}

Bacchi, C. L. (1999). Women, Policy and Politics: The Construction of Policy Problems, Thousand Oaks, CA: Sage.

Bacchi, C. (2009). Analysing Policy: What's the Problem Represented to be? Frenchs Forest, Australia: Pearson Education.

Bacchi, C. (2012). Introducing the 'What's the Problem Represented to be?' approach. In Bletsas, A. and Beasley, C. (eds.) Engaging with Carol Bacchi: Strategic Interventions and Exchanges, University of Adelaide Press.

Bacchi, C. (2018). Drug problematizations and politics: deploying a poststructural analytic strategy, Contemporary Drug Problems 45(1): 3-14. doi: https://doi.org/10.1177/ 0091450917748760.

Bacchi, C. \& Goodwin, S. (2016). Poststructural Policy Analysis: a Guide to Practice, Palgrave Macmillan.

Børing, P. \& Gunnes, H. (2012). Internasjonal rekruttering til norsk forskning [International recruitment to Norwegian research]. NIFU-report 4-2012: Available at: http://www.nifu. no/publications/1026723/.

Dennissen, M., Benschop, Y. \& Van den Brink, M. (2018). Diversity networks: networking for equality? British Journal of Management, doi: https://doi.org/10.1111/1467$\underline{8551.12321 .}$.

Ferdman, B. M. (2014). The practice of inclusion in diverse organizations: Toward a systemic and inclusive framework. In Ferdman, B. M., Deane, B. R. (Eds.), Diversity at Work: The Practice of Inclusion (pp. 3-54), San Francisco, CA: Jossey-Bass.

Gunnes, H., Nordby, P., Næsheim, H. \& Wiig, O. (2017). Mer mangfoldstatistikk. Statistikk om innvandrere og etterkommere av innvandrere i norsk forskning og høyere utdanning [More diversity statistics. Statistics on immigrants and descendants of immigrants in Norwegian research and higher education] Revised version. NIFU Nordisk institutt for studier av innovasjon, forskning og utdanning: Available at: http://www.nifu.no/publications/ $1464389 /$ [10.12.15].

Ivancevich, J. M. \& J.A. Gilbert (2000). Diversity management: time for a new approach, Public Personnel Management 29(1):75-92.doi:https://doi.org/10.1177/009102600002900106.

Janssens, M. \& Zanoni, P. (2014). Alternative diversity management: organizational practices fostering ethnic equality at work, Scandinavian Journal of Management 30: 317-331.

Jonasson, C. Lauring, J. \& Guttormsen, D. S. A. (2018) Inclusive management in international organizations: how does it affect local and expatriate academics? Personnel Review 47(2): 458-473. doi: https://doi.org/10.1108/PR-12-2015-0323.

Maximova-Mentzoni, T., Egeland, C., Drange, I., Askvik, T., Støren, L. A.; Røsdal, T., Vabø, A. (2016). 'Being an immigrant is no advantage': career paths and barriers for immigrants in Norwegian academia. Research report 2016: 12, Oslo: Work Research Institute (AFI). Available at: http://kifinfo.no/sites/default/files/r2016 12 beingaforeigner.pdf [link 05.02.19].

Nkomo, S. \& Hoobler, J. M. (2014). A historical perspective on diversity ideologies in the United States: reflections on human resource management research and practice, Human Resource Management Review 24: 245-257.

Osborne, T. (1997). Of health and statecraft. In A. Petersen, \& R. Bunton (Eds.), Foucault: Health and Medicine, London: Routledge.

Prasad, P. \& Mills, A. J. (1997). From showcase to shadow: Understan ding the dilemmas of managing workplace diversity. In Prasad, P., Mills, J. A., Elmes, M., Prasad, A. (Eds.), Managing the Organizational Melting Pot: Dilemmas of Workplace Diversity, London: SAGE Publications: 3-27. 
Shore, L.M., Randel,A.E., Chung, B. G., Dean, M. A.,Holcombe Ehrhart, K. \& Singh, G. (2011). Inclusion and diversity in work groups: a review and model for future research, Journal of Management 37(4): 1262-1289. doi: https://doi.org/10.1177/0149206310385943.

Yin, R. K. (2004). The Case Study Anthology, Thousand Oaks, CA.: Sage.

Zanoni, P., Janssens, M., Benschop, Y. \& Nkomo, S. M. (2010). Unpacking diversity, grasping inequality: rethinking difference through critical perspectives, Organization 17: 9-29.

\section{Notes}

${ }^{1}$ Nationality diversity refers to the variety of nationalities among academic staff and is used interchangeably with 'foreign-born academic staff'.

${ }^{2}$ The research project was carried out by The Work Research Institute (AFI) and The Nordic Institute for Studies in Innovation, Research and Education (NIFU) in the last half of 2015 and financed by the Norwegian Committee for Gender Balance and Diversity in Research (KIF).

${ }^{3} \mathrm{~A}$ list of references to these papers are included just above the reference list for this article. 